\title{
Poetry in Translation: Traveling Pleonasm and Beyond
}

\author{
RAJA LAHIANI \\ UAE University, \\ United Arab Emirates \\ raja.lahiani@gmail.com
}

\begin{abstract}
Style is the kernel of literariness. This study examines the translatability of pleonasm, a form of redundancy considered a standard rhetorical device in Arabic but usually avoided in Western languages. The study evaluates and compares English and French translations of a pleonastic Arabic verse line. An acceptable translation of this verse should provide an affective-stylistic equivalent that will capture and convey the same appeal as the source text with a similar degree of literariness, not just a direct linguistic equivalent. This research asserts that a translator usually works within their own translation aesthetics, developed within their cultural and disciplinary traditions of literary and translational aesthetics and their idiosyncratic ideas about or interpretation of the source text.
\end{abstract}

Keywords: literary translation; redundancy; translating style; pre-Islamic poetry; translation quality assessment

\section{INTRODUCTION}

Literary translation is fundamentally the translation of style. Style defines the borderline between literary and non-literary texts while simultaneously unifying them at a fundamental level. The formal aspects making up style not only deliver information but also shed light on the author's state of mind and attitude and make up a unified standard repertoire for literary tradition into a language. Style is governed by choice; Boase-Beier ${ }^{1}$ views it as "possibly the least contentious area of translational freedom" (2020: p. 64) and affirms that a "stylistically aware reading of the source text [...] aims to reach a full and detailed picture of the inferred author's choices, not [...] an actual author's choices" (2020: p. 60). At the same time, she notes, this situation is reciprocal, as the style that a translator chooses "is subject to all manner of constraints and influences" that they may be only faintly aware of (2020: p. 65).

In short, style is the seed of the literary; literariness is governed by the writer's structural and verbal choices and the literary tradition they work within. Style, like translation techniques, strategies, and norms, is culturally and historically variable, which justifies Koster's consideration of a work's stylistic features as translation challenges (2014: p. 151). Cultural variety leads to translation, and translation is the product of cultural exchange (Debbas \& Haider, 2020: p. 3). To Koster, the translator reconstructs the source text's (ST) intended message by reconciling means and effect, much as the ST author adopts alternatives from a repertoire of possible ways of expression to build certain aesthetic, literary, or narrative effects: "It is the translator's task to make choices from the repertoire of possible means of expression from his language in order to transfer the perceived source text's intention, to find the means to bring about analogous effects and a corresponding narrative" (Koster, 2014: p. 151; see also Boase-Beier, 2017: p. 482). Koster further explains that the "problem is not so much located in the means or effects in themselves but in the relationship between the two" (2014: p. 152). Similarly, Scott argues that a translator is expected not to render the ST's linguistic elements exactly as they occur in the target text (TT), but may, when the intrinsic demands of the text demand it, seek effect in the paralinguistics of the TT: "in certain vocal inflections or rhythmic choices, in certain dispositional and/or typographical maneuvers, wherever the reader's psycho-physiological or kinesthetic relationship with a text 'deepens' and ramifies" (2015: p. 
8). Likewise, Underhill highlights the synergetic relationship between form and meaning in poetry (2016: p. 41).

Certainly, it is agreed that translation is a "highly constrained activity" occurring within an arena of tension between two clashing ideals: fidelity to the source text's realities and loyalty to the target language's exigencies (Krein-Kühle, 2014: p. 16). Baker asserts that selective appropriation is used in every translation, as "the resources provided by each language inevitably oblige the mediator to make choices that involve suppressing some elements and foregrounding others" (2014: p. 167). Moreover, the ST's original receivers are in general expected to be familiar with its background, and thus should not fail to complete on their own the message that the poet intends: "poetic effects arise essentially when the audience is induced and given freedom to open up and consider a wide range of implicatures, none of which are very strongly implicated, but which taken together create an 'impression' rather than communicate a "message"' (Gutt, 1991: pp. 156-157). This presents a further challenge in translation; as Boase-Beier notes, translated poetry requires more effort by the reader to create a context supporting interpretation, and thus, the translation process can be considered "to have enhanced and intensified many of the poetic elements of the source text [...] stylistic study of translated texts might be expected to find that such texts possess literariness to a high degree" (2020: p. 79; Sullivan, 2019: p. 268). Poetic language is often hard and almost never straightforward, even within the same cultural background, which in (e.g.) "English," "French," or "Arabic" covers a multitude of disparate contexts within a single language.

Translated Arabic poetry performs a significant, indeed vital, socio-cultural, and literary role in the lives and education of many of its readers. Its specificities and the degree to which its translations preserve them and maintain communicative reliability-speak for the originals - deserve attention within the disciplines of comparative literature and translation studies. In this study, we consider the translation of a pleonastic verse line from a classical, canonical Jāhilī (pre-Islamic) poem. Pleonasm is common in classical Arabic poetry and in the Holy Quran, and performs several communicative rhetorical functions (Al-Adwan and Abuarabialedwan, 2019: p. 50). This study evaluates to what degree the translations are representative of the original in terms of appeal and function.

The pre-Islamic qașida (a relatively long, mono-rhymed bi-hemistich poem) is part of the oral tradition of Arabic literature, usually studied as both musical composition and logically connected verbal utterance. Most often, receivers were familiar with the subject treated by the poet, and would thus listen "in expectation of how he would proceed in unfolding the wellknown pattern of the qașidah" (El Tayib, 1983: p. 29). The sequential thematic structure of the classical Arabic qașìda runs through a ternary archetype: yearning for a lost love (nasīb); departure, with a description of the mount - the camel or the horse (rahîll); and self-praise (fakhr). The Arab poet was not a narrator: "He was a master of brevity, a magician of rhythm and words [...]. Hence, from ancient times, Arabic poetry required its commentators-cumtransmitters" (El Tayib, 1983: p. 29). This poetry is so condensed, rich, and crafty that it needed commentators to analyse it and explain its imagery and appeal even to its contemporary receivers. Stetkevych perceives the qașìda "as framing structure and poetic vehicle" (1993: p. 2); to him, "poetic content" in this mode "not only survives but flourishes [...] and extracts out of its predicament a strange power and solidity of imaginative impact" (1993: p. 5). Pre-Islamic qașidas are usually subject to open-ended analyses and explanations - their major strength. Within their framework, "form becomes its own content, a sui generis unity becomes perfect, as may be seen in the arabesque. Such a structure brings content in a material sense much closer to form than loose, outstretched panels or discourses of an epic nature" (Stetkevych, 1993: p. 4). As such, when interpreting a qașida, form and content are inseparable. The verbal phrasing of a qașida steps across its cognitive contours, leading to inklings of another sphere of meaning; this, in turn, leads to a deconcretisation of mood that, in a way, clings to cognition. From this 
perspective, Stetkevych calls for "apprehending the specificity of the poetic mood as it hierarchically rules the poem's subjects and themes and determines their integration into the structure of the poem" (1993: p. 17).

The Mu'allaqāt is a collection of seven prize canonical pre-Islamic qașidas of the Arabian Peninsula, compiled around the seventh century AD (Lyall, 1986: p. xxxv). ${ }^{2}$ Tarafa (539-569) was one of the contributors; he was a noble scion who grew up caring for nothing but the extravagant life and high-calibre versification, and his biographies reveal that he was frequently rejected by his tribespeople because of his bohemian lifestyle. He composed his Mu'allaqa to seek pardon from his relatives for one of his feckless deeds. Tarafa had been assigned to watch his elder brother's herd but was so immersed in composing poetry and reciting it aloud that he let the animals wander off. This assignment was, he was told, his last chance to be reintegrated in his tribe. (Arberry, 1957: pp. 68-71). These special circumstances led him to modulate the poem's structure, making the rahīl and fakhr much longer than the $n a s i \bar{b}$; thus, much of Țarafa's qașìda consists of meditations upon his own worth, self-pride, and adherence to his tribe's values, such as chivalry.

Țarafa adhered to muruwwah, a pervasive, totalising ideal in pre-Islamic Arabia reflected in all seven $M u$ 'allaqät, which encompassed all the virtues that would preserve one's (tribe's) honor: helping the needy, protecting the weak, defending honor, offering shelter to nomads, and tribal solidarity. Evidently, Tarafa's adherence to muruwwah and his need to meditate upon it urged him to extend his fakhr section, to exhibit his own worth and the benefit he (usually) brought to his tribe. Fakhr is of two subtypes: personal, where the poet praises his own value, and "tribal fakhr, [where] the tribe becomes the paradigm of muruwwah and the poet, without losing his individualism, merges with the tribe [...;] personal fakhr implicitly functions as a glorificatory foil to the tribe" (Montgomery, 1986: p. 6).

\section{CASE STUDY}

Demonstrating his muruwwah by boasting of his positive qualities and exploits, and thus his worth as a brave warrior within his tribe, Tarafa announces that if summoned to defend his tribe, he will be ready:

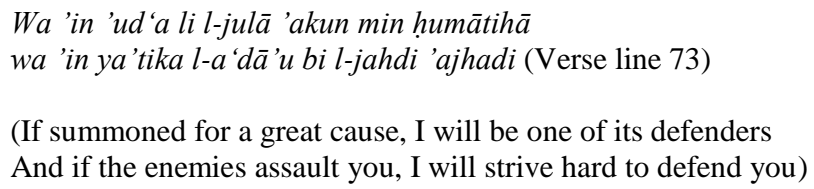

These lines from the fakhr reflect the total outcome of the qașida's third act, as described by Stetkevych: "whether it is phrased as a panegyric or as a collective tribal exultation, is, as mythopoesis in its own right, a proclamation and rhetorically enhanced celebration of arrival" (1993: p. 40). Pleonasm is an "expression which is semantically redundant in that it merely repeats the meaning contained elsewhere, in what precedes or follows it" (Leech, 1984: p. 132); in its repetitiveness, highly characteristic of oral poetry (Monroe, 1972: p. 15). The verse line above is doubly pleonastic, both rephrasing the second hemistich of verse line 72 in the same $\mathrm{Mu}$ 'allaqa $^{3}$ and rephrasing the content of its first hemistich, on Tarafa's determination to protect his tribe, in the second one.

The context vindicates the poet's pleonasm: this is Tarafa's bitter lamentation at being rejected by his tribe, contrasting his exclusion with the truth that he is an asset that the tribe should not sacrifice. The poet thus asserts his adherence to muruwwah at both the personal and tribal levels. His repetitive expression of courage and readiness to help amplify the receiver's 
awareness of his putative muruwwah. This is highlighted even further by the antithetical relationships established between hemistichs in each line: the verb $u d$ ' $a$ (summoned) in the first hemistich finds its antithesis in ya'tika (assault) in the second, as does humātiha (defenders) in jahd (strive). The antithetical relationship between hemistichs bears twofold importance: it directs the verse line receiver to perceive the reaction to danger from two perspectives, the poet's and the enemy's; and it undertakes the basic function of pleonasm.

In the first hemistich, Tarafa uses the word jula, meaning a great cause. Placed in a conditional clause, this word is linked by parallelism to humātih $\bar{a}$, literally the defenders of a tribe. ${ }^{4}$ Thus, the great cause, jula, must be invasions by enemies. This implicit meaning becomes explicit when rephrased in the second hemistich, as the poet speaks about enemies and his readiness to fight them back. He uses a polyptoton ${ }^{5}$ in linking the words jahd and ajhadi. The sounds used in the root of these words (jahada), /3/ and /h/, are obstruent sounds, which classifies them as hard sounds according to Leech's scale (1984: p. 98); ${ }^{6}$ this hardness is in line with the verse line's appeal. Tarafa's style unfolds an element of "forthrightness coupled with a purity of diction, not labored, but forceful and energetic [culminating in a] spontaneous flow" (El Tayib, 1983: p. 34). The verse line dealt with here is forthright in that it uses simple lexical elements, and these acquire intensity by means of the sounds embedded in them; therefore, the pleonasm and the antithetical parallelism used, highlight the poem's appeal.

Thus viewed, this sample verse line will be acceptably translated not by a linguistic equivalent but rather by an affective stylistic equivalent that would capture and convey the same appeal as the ST with a similar degree of literariness. This study adheres to Boase-Beier's argument that the "style of the source text, the perceived cognitive context of that text's author, the function the translation is expected to fulfil, considerations of closeness to the style of the source text or distance from it - all these factors influence the choices the translator makes" (2020: p. 70). This is because translating poetry is "not merely to translate the source text as product, but to reconstruct the poetics of the original poet" (Boase-Beier, 2017: p. 483). Otherwise, the translation could suffer from a "deceptive correspondence" (Shen and Fang, 2019: p. 328) if it targets linguistic equivalency.

Arabic is considered a language that tolerates repetition in its different forms to a considerable extent. In contrast, rhetorical and stylistic norms in English do not tolerate as much repetition. Leech considers the use of pleonasm in English to be "a culpable form of redundancy" (1984: p. 137). This stance is far from unique to English; French, for example, classifies the excessive use of repetition-based statements as non-elegant or even improper (Al Khafaji, 2010: pp. 186-187). Repetition is usually avoided in English and French but has certainly been used in them to great effect; thus, the difference is not that it is not a rhetorical device in other languages, but that it is heavily used in Arabic and is part of the basic repertoire.

By evaluating translations of this verse line, this study seeks to investigate whether a literary device, pleonasm, as shall be explored below, bears a stable value, and is thus conventionalised and static, or whether it is dynamic, and hence aesthetic and functional. A corpus of thirteen translations was gathered to delve into a comparative evaluation. The publication dates of these translations range between 1782 and 2000. Five of them were translated into French and the rest into English. The choice of these two target languages was due to their similar handling of pleonasm, the main experimental tool in this research work. Four translations were made into prose, and nine into verse. The inclusion of verse and prose translations was due to the author's belief that these modes of discourse and stylistic awareness are by no means in conflict. The translators' dates and motives were researched in order to gain deep insight into their translations of this pleonastic verse. French and English bear no norms stipulating that pleonasm needs to be translated into a similar scheme; it is, thus, the translator's awareness of the aesthetic and functional roles of pleonasm that determines the acceptability 
of their work. Assessment in this article was done at the diachronic and synchronic levels. At the same time that the chronology was respected, similarities and differences between translations have been revealed. This is intended to spread dynamism in this research work.

\section{COMPARATIVE ANALYSIS}

The implicitness and explicitness of both ST hemistichs given above were used by most of the translators to conceal the redundancy embedded in the ST pleonasm, and hence, give the illusion that the poet presented two ideas rather than one. For instance, William Jones (17461794) and Caussin de Perceval (1795-1871) rendered this verse line, respectively, as follows:

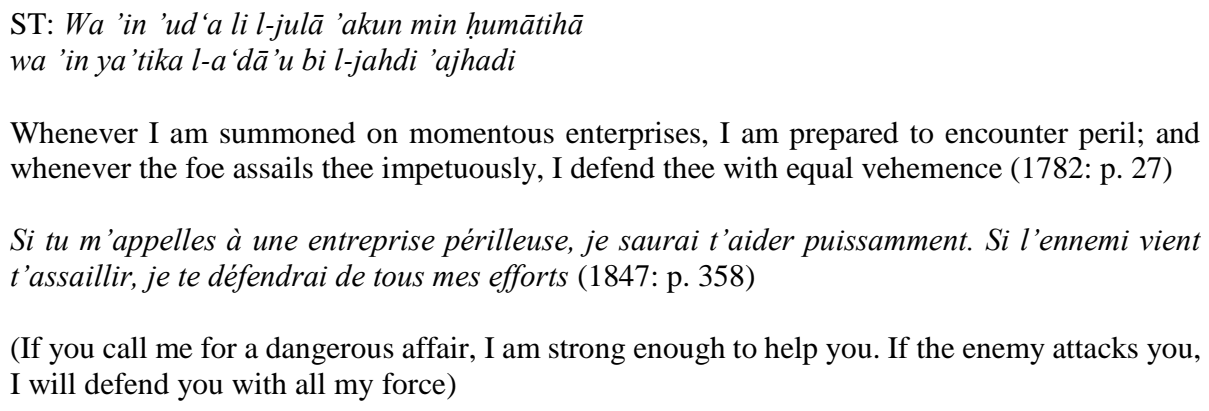

As can be seen, both translators thoroughly effaced the traces of pleonasm. Having ignored the fact that the ST jula intentionally stands for invasion by other tribes, Jones and Caussin de Perceval took all the freedom necessary to produce a metonymical modulation by rendering the specific term humāt into a much more general expression of encountering "peril" or of "aider puissamment." Their specific means of doing so lie in the way they manipulated the ST pronoun $h \bar{a}$. While Jones shaped the structure of his clause in a way that enabled him to avoid this pronoun with its implicature, Caussin de Perceval changed the original structure from the passive to the active voice in an attempt to incorporate the second-person pronoun, as in the second hemistich of the original verse line. Thus, when one reads in the second part of these renderings about a "foe" or "ennemi" who might assail the poet's tribe, one will interpret it that the poet is talking about another issue, and not repeating the same idea. Likewise, when Jones and Caussin de Perceval respectively use in the second part of their translations the expressions "I defend thee with equal vehemence" and "je te défendrai de tous mes efforts," they do not give the impression that the same idea was repeated. The appeal of the ST is present in both translations, as both communicate the poet's embodiment of the muruwwah ideal. Note that one of Jones' motivations for translating pre-Islamic poetry is to make accessible to the English-language reader a poetry in which "vehement passion is expressed in strong words, exactly measured, and pronounced, in a common voice, in just cadence, and with proper accents" (1993: p. 133); both the intensity and the message are thus preserved here. As for Caussin de Perceval, historical and cultural data were what he prized most in his translations of Arabic poetry, as made clear in the title of his book: Essai sur l'Histoire des Arabes Avant l'Islamisme, Pendant l'Epoque de Mahomet, et Jusqu'à la Réduction de Toutes les Tribus sous la Loi Musulmane (An Essay on the History of the Arabs before Islam, During Mahomet's Era, and Until the Conversion of All the Tribes Under the Muslim Law). These two efforts call attention back to the claim that style is important for both message and literariness.

Johnson's (1796-1876) rendering is quite different from these earlier translations:

ST: Wa 'in 'ud'a li l-julā 'akun min ḥumātihā

wa 'in ya'tika l-a'dā'u bi l-jahdi 'ajhadi 
And if I am called on by you in any serious affair, I will be amongst the defenders of your honour, and if the enemy comes to you, striving for your destruction I will strive in repulsing him (1893: pp. 55-56; italics in original)

Despite the fact that he translated humātihā into "defenders," Johnson still attempted to mask the ST pleonasm in two ways. First, he introduced a difference between the danger mentioned in the first hemistich, and that stated in the second one. One would understand from Johnson's rendering that the poet started by expressing his readiness to defend his tribe's "honour" and then moved on to speak about his ability to defend the tribe itself, per se, against raiders. Johnson italicised the strings that he added in an attempt to make his interpolation visible; both defending one's "honour" and protecting a tribe against "the enemy" are "serious affair[s]" that require "serious efforts." Thus, he simultaneously masks the pleonasm but preserves a path back towards it. The second strategy that Johnson follows lies in his rendering of the ST's derivative repetition into a polyptoton, by means of which he managed to keep part of the original pleonasm. That is, the repetition of the verb strive in different grammatical inflections helped him refer back, indirectly, to the word "defenders" that he used while translating the first hemistich. Semantically speaking, the clause "I will strive in repulsing him" bears much the same value as "I will be amongst the defenders." In the midst of these modulations, Johnson manages to preserve the poet's appeal to muruwwah, though the intensity that is inherent in the ST's literariness is weakened. This may be justified by the fact that Johnson's translation was produced for didactic reasons (1893: Preface).

Schmidt (1939-) partially followed the steps of the pioneering prose translators, but also improved on them:

\author{
ST: Wa 'in 'ud'a li l-julā 'akun min humātihā \\ wa 'in ya'tika l-a 'dā'u bi l-jahdi 'ajhadi \\ Si, dans le danger, tu m'appelles à l'aide, je serai là pour défendre ton bien, et si l'ennemi t'attaque, je \\ t'en préserverai (1978: p. 91) \\ (If, in danger, you call me for succor, I will be there to defend your possessions, and if the enemy attacks \\ you, I will preserve you)
}

Note here the difference in length between the rendering of the first hemistich and that of the second. The special care with which Schmidt handled the first hemistich is visible. To start with, it is important that he rendered $u d$ ' $a$ into a French idiom: "tu m'appelles à l'aide" (you call me for succour); none of the previously quoted translators referred to "succour" in rendering this Arabic verb (though Schmidt was not the first to do so; see below). Not only does he use an idiom, but Schmidt also backs it with the clause "je serai là pour défendre ton bien" (I will be there to defend your possessions). In addition to his use of the verb "défendre" (defend), Schmidt uses the object "ton bien" (your possessions); bearing a trace of the ST $h \bar{a}$; this phrase clarifies the main concern of the poet, which is the defense of his tribe's possessions. Above, the translators added an object at this level of the TT sentence that referred to defending the addressee's honor, breaking with the ST pleonasm; in contrast, Schmidt's use of the phrase "ton bien" helps preserve the ST pleonasm. Then, in his translation of the second hemistich, he rephrases, as in the ST, the idea of the first hemistich without giving the impression of redundancy. In this context, "danger" finds its equivalent in "attaque," while the meaning of "défendre" is reflected in "préserverai." However, as the second hemistich shrinks in Schmidt's rendering, the emphasis that stands at the heart of the ST verse line is diluted. In addition, Schmidt creates in this part a contrastive parallelism between "l'ennemi t'attaque" and "je t'en préserverai," as a compensation for the ST polyptoton; different as it is from the style used in the first part, this condensed parallelism gives to some extent the illusion of a new idea. 
Anne Blunt (1837-1917) and Wilfrid Blunt (1840-1922) are chronologically the first verse translators in the corpus. Their translation was collaborative; she rendered the ST into English prose, and he versified her translation (1903: p. xxi):

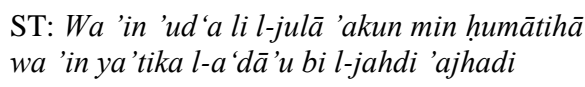

One may trace in this rendering the first concrete reference to help ("succour") in the translation of the first hemistich. ${ }^{7}$ By means of this reference, the Blunts diverge from the ST's progression from implicitness to explicitness, instead of creating another progression as they move in their couplet from a general argument to exemplification. The general argument is a condensed summary of the content of the ST verse line, so brief that it expands on only half a line; in this half-line, the inference of the original pronoun $h \bar{a}$ is rendered into a concrete reference to "tribes." As for the exemplification, it has no antecedent in the original verse line, but it does bear a trace of the Jāhili social life: the Blunts talked about the women of the tribe who would be captured because their tribespeople could not defend them. The Blunts' Tarafa announces that he is much stronger than the raiders and can defeat them, and hence, defend the women. In this context, the Blunts' reference to women is crucial, because women had used to be considered one of the most important of a tribe's assets to defend, and if they were abused, the tribe's honor was stained. ${ }^{8}$ Bearing in mind the context of this verse line in the Mu 'allaqa, it is quite positive that the Blunts drew this image from the line's larger context. A prior attempt in this vein was also made by Johnson, who referred to defending the tribe's "honour"; more concretely, Schmidt referred to what the poet might protect in his tribe: "ton bien." The Blunts' choice to talk about women explicitly is, of course, still more concrete. Tarafa aimed to appeal to his relatives by expressing his readiness to defend them; the Blunts support him by giving him a key with which to convince his audience (putatively, as that audience would, of course, not read the translation). When it comes to preserving the tribe's honor, Tarafa's tribespeople should then be ready to re-integrate him, as he is presenting himself as "mightier" than the oppressors. It is equally important that this Tarafa claim that it is the women who would "cry" "loudly" for his help, and not he who might spontaneously offer the needed "succour" to them. This meaning is created by the Blunts' use of the prepositions "from" and "to" to represent the women escaping from their oppressors and seeking refuge in the poet. Again, this matches the general context of the ST verse line: at the same time that he asks for reintegration, Tarafa is still concerned to preserve his self-pride and dignity; that is, his muruwwah. Furthermore, it is his muruwwah that makes his reintegration desirable, in principle, from the perspective of the tribe. The Blunts' calling back to these traits in this verse line is not, thus, out of context. The Blunts were active during the Victorian age, an age when women's "rights were hotly debated and relatively acquired" (Lahiani, 2008: p. 54). The Blunts express, in the introduction to their translation, their admiration of the position of women in pre-Islamic Arabia and their interest in its manifestations (1903: pp. xiii-xiv). In addition, these translators meditate upon the values of muruwwah that reverberate in the Mu'allaqāt (1903: pp. xi-xii).

In these radical changes, the ST pleonasm is very little in evidence; the example that the Blunts created came as a replacement for the original redundancy. It is probable that the Blunts made such a shift because the idea of this verse line was already expressed in the second hemistich of the previous one, as preserved by the Blunts: 
The comma at the end of the line above reflects the Blunts' awareness of the semantic and thematic continuity between verse lines 72 and 73; thus, their condensation of the meaning of verse line 73 into half a line and their choice to substitute an example for the pleonasm become clear. What the Blunts did not perceive, though, was the special functionality of the pleonasm and of the parallelism between both ST verse lines. Expressing similarity, this parallelism helps convey the passionate strength of the poet's appeal to his tribespeople, and the redundancy of the pleonasm reinforces this function of parallelism. Thus, despite the fact that the Blunts did respect the inner and outer contexts of the Mu'allaqa, their work with this verse line is more like an adaptation than a translation.

Arberry (1905-1969) did not follow the Blunts' daring steps, although he was aware of their work. His translation has its own peculiarities:

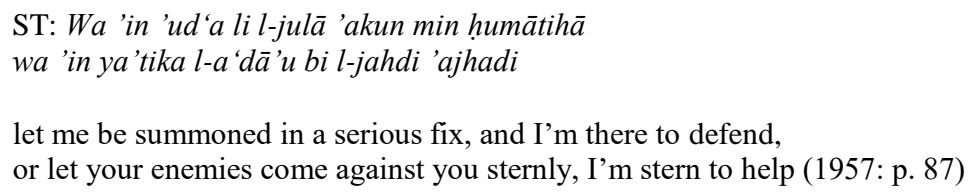

The first notable characteristic of this translation lies in Arberry's change from the ST's conditional mode to the imperative mode. The imperative here communicates invitation: the poet urges his tribespeople to test his worth and readiness. Arberry uses the conjunction "or" to set the link between the ideas in the two ST hemistichs. None of the other translators in the corpus used this conjunction; whereas most of them used "and"/“et," some used punctuation marks like the full stop (Caussin de Perceval, 1847; Sells, 1986), the comma (O'Grady, 1990; Larcher, 2000a), or the slash (Berque, 1979). Conveying the existence of alternatives, the conjunction used by Arberry reinforces the function of pleonasm in the TT. At the surface level, the reader of Arberry's translation may reach the illusory understanding that the poet gave his tribespeople two different alternatives; at a deeper level, however, it is quite clear in this translation that, as in the ST, there is a movement in the verse line from implicitness to explicitness to express the same idea.

This movement is guaranteed by two means in this translation. The first lies in masking the object of the transitive verb "to defend" and then stating it concretely in the second line, to avoid ambiguity. The second means is the synonymous parallelism between the strings "a serious fix" and "your enemies come against you sternly," and between "defend" and "help." The movement is also conveyed by maintaining the polyptoton, as in the ST; using the root "stern" with two different derivations helps Arberry reflect the equality in power between the enemies and the poet as in the original verse line. These strategies help Arberry make his translation coherent and consequently acceptable to its receiver, yet also akin to its original.

Berque (1910-1995) and Sells (1949-) preserved the ST polyptoton, too, although they did not make it as functional as Arberry did:

ST: Wa 'in 'ud'a li l-julā 'akun min humātihā

wa 'in ya'tika l-a'dā'u bi l-jahdi 'ajhadi

si l'on m'appelle pour une grande chose, je suis parmi ceux qui la soutiennent / si les ennemis roidement t'assaillent, ils trouvent en moi même roideur (1979: p. 156)

(if called for a big issue, I am amongst those who would support her / if the enemies swiftly assail you, they will find in me personally the same stiffness)

Called on in trouble,

I defend.

If enemies come straining against you

I strain back (1986: p. 30) 
Both translators created puns in order to render the ST polyptoton. While "roidement" and "roideur" in Berque's lines are derived from the same root, they convey two different meanings; the former is an adverb that means swiftly, while the latter is a noun that conveys rigidity (Le Robert, 1974). Varying the meanings of these words with the variation in their morphogrammatical form reveals the translator's attempt to partially avoid the redundancy that pleonasm creates in the original verse line. ${ }^{9}$ In fact, his rendering of the second hemistich of verse line 72 helped him a great deal in masking this redundancy:

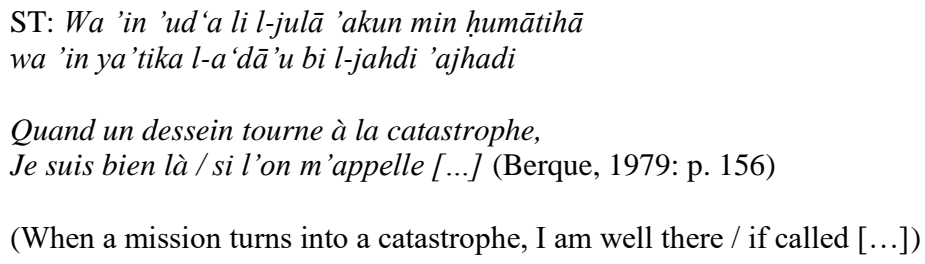

Clearly, this rendering is defective. The word "dessein" (mission) that Berque used is far from conveying the meaning of the ST nakitha (extensive efforts). Hence, Berque's attempt to omit the redundancy inherent between both verse lines weakens the original message. As for Sells, he uses the word "straining," meaning forcing oneself beyond the limit, and "strain," meaning making the greatest possible effort (OED). Contrary to Berque's translation, the pun enables Sells to preserve the ST pleonasm. Like Arberry, though, Sells' translation of verse line 72 turns Țarafa from an active agent to a simple "witness," which effaces the message originally intended:

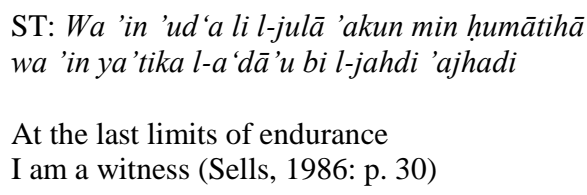

These two translations are also dissimilar in several other details. For instance, while Berque's lines are long and include relatively many clauses, Sells's lines are rather short, imitating the compression of the original verse line. This lack of wordiness directs the reader towards the chief concern of the quatrain. Thus, while Arberry used the phrase "a serious fix" and Berque the ambivalent expression "une grande chose," Sells used one word, "trouble." Likewise, whereas Berque used the clause "ils trouvent en moi même roideur," Sells used "I strain back." This succinctness enabled Sells to highlight the conditional cause-effect relationship that is basic to the ST verse line. In addition, the second and fourth lines of his quatrain are much shorter than the other lines, for an important reason: these lines express the poet's resolution and determination to serve his tribe. Thus, it is important that they come as short clauses formulated in the declarative mode; wordiness might have implied hesitancy. In addition, it is revealing that Sells uses verbalisation; it conveys Tarafa's (expressed) will to act. The difference between Sells's "I strain back" and Berque's "ils trouvent en moi même roideur" cannot be missed. Sells's translation rightfully connects the poet's determination to the act; contrarily, Berque's rendering wrongly conveys the poet's passivity, as the clause starts with a third-person pronoun, and the expression "en moi" (in me) turns the speaker into a recipient rather than an agent. The same applies between the clauses "je suis parmi ceux qui la soutiennent" (I am amongst those who would support her; Berque, 1979) and "I defend" (Sells, 1986). To be noted here is that Sells mentions that one of his strategies in translating ancient Arabic poetry is the use of "cadence, as modulated through the line breaks, to re-create the original rhythmic texture formed by the play of syntax across meter" (1989: p. 8). 
The length of the lines is also important in the reception of pleonasm in these two translations. The wordiness in Berque intensifies the reader's consciousness of redundancy; the appeal that the ST intended to achieve by means of pleonasm is also lost, because of Berque's attempt to emulate the ST pronouns. In contrast, pleonasm conveys in Sells's quatrain the same function as in the ST; this is achieved not only by means of short lines but also by the semantic progression produced between the clauses "I defend" and "I strain back"; that is, in terms of intensity, straining is much stronger than defending. This variation gives the illusion that the poet presented a new idea in the second half of the quatrain distinct from what he claimed in the first part. The translation strategies Sells used here line up with what he says in the prelude to his translation: "Through unrhymed quatrains and the play of syntactical cadence against the line breaks I attempt to recreate the original's inner rhythmic texture" (1986: p. 23) while also producing a text "in a natural, idiomatic, and contemporary American verse" (1989: p: 8). ${ }^{10}$

Larcher's (1948-) translation ${ }^{11}$ is the closest in the corpus to Sells's work in terms of the choices made. Much like Sells, Larcher intended his translation to use a language and a style that is, at the same time, academic (2000: p. 26) and appeals to the modern reader (2000: p. 21). In addition, although aware of most of the French and English translations that were published before his, Larcher's translation proffers special tribute to Sells's translation (2000: p. 60):

\author{
ST: Wa 'in 'ud'a li l-julā 'akun min humātihā \\ wa 'in ya'tika l-a 'dā'u bi l-jahdi 'ajhadi \\ Appelé à l'action, je suis de ses soutiens, \\ Les ennemis t'attaquent-ils, je contre-attaque (2000: p. 68) \\ (Called for action, I support it, / would the enemies attack you, I would counterattack)
}

While Sells versified his lines into quatrains, Larcher opted for couplets. As already seen above, the quatrain helped Sells vary the length of lines and make this variation functional; the couplet, in contrast, enables Larcher to get close to the ST double-hemistich form. Deeper scrutiny of Larcher's translation will prove its superiority to Sells's; for example, Larcher's translation of the second hemistich of verse line 72:

Quand affaire requiert énergie, je suis là (2000: p. 68)

(When an affair requires energy, I am available)

This line paves the way for the poet to expand on his physical readiness to defend his tribe. As discussed above, Sells's lines by no means do so. In addition, one perceives in Larcher's couplet an attempt to imitate the ST's sound effects; this may be seen in the assonance he produces in the first line by repeating the /a/ sound in the clause "appelé à l'action," which is reminiscent of the ST verse line's repetition of the sound $/ \mathrm{a}^{2} /$ in the words "'in," "'ud ' $a$," and "'akun." The verbs Larcher uses are reminiscent of Schmidt's prose translation, but Larcher's skills manipulated them in such an aesthetic way as to fit into a poetic musicality. Likewise, Larcher was visibly risk-averse and evidently worked hard to evade the risk of wordiness and to secure the ST's intensity of expression and movement from implicitness to explicitness using caesuras. Both target lines include these metrical breaks, which consolidates the parallelism that ties up the ST hemistichs together and also accelerate the tempo, which is fueled by the repeated occurrence of the word "attaque" (attack).

Desmond O'Grady (1935-2014) followed the same strategy as Sells and Larcher in writing short clauses, although the way he translated the original is different: 


\author{
ST: Wa 'in 'ud'a li l-julā 'akun min humātihā \\ wa 'in ya'tika l-a 'dā'u bi l-jahdi 'ajhadi \\ My people insulted, I reply with vengeance (1990: p. 29)
}

This translation assimilates both ST hemistichs into one line, thus, obliterating the original pleonasm. This assimilation carries with it a parallelism based on a cause-effect relationship: whereas the cause in the ST moves from the implicit to the more explicit, that is, from talking about julā to mentioning enemies, O'Grady reduces both actions into the verb "insulted," which narrows the communicative scope of the text. While Tarafa originally asserts that his tribe needs his help in wartime, O'Grady marginalises this message, as avenging an insult does not equal avenging the raid of another tribe or staining its honor. O'Grady reduces the speaker's retaliation to personal rather than tribal muruwwah. This reduction has already started with O'Grady's rendering of the second hemistich of verse line 72:

Faithful to friends, I'm always ready to help (ibid.)

Being ready to help is not intense enough to fit the context of raids and defending the tribe, and hence, the speaker's exhibition of his muruwwah. O'Grady's reference to friends weakens his translation even further, as the context of the whole $M u$ 'allaqa is the position of the poet in his tribe and amongst his tribespeople, and mentioning friendship is, thus, out of context here, as the pre-Islamic society was centred on kinship rather than friendship. O'Grady intentionally adopts throughout his translation of the $M u$ 'allaqāt, a strategy of mitigation (Lahiani, 2008: pp. 221-223; 242; 252-253), and goes as far as omitting verse lines and refraining from translating them. ${ }^{12}$ The processes of mitigation and omission that are exercised by O'Grady may be justified by his tendency to make the $M u$ 'allaqāt appeal to the modern reader of English by reconciling them with modern TT-reader assumptions (1990: p. 8). ${ }^{13}$ Paradoxically, O'Grady showed a deep interest in Țarafa's biography (1990: pp. 22-24) and the background behind the composition of this text and did not trouble to justify his omissions and lack of compensation for them. Such reductions in effect and affect, in turn, trigger and activate the need for an ambivalent norm in translation.

Christopher Nouryeh (1940-) opted for a somewhat different strategy to handle the pleonasm in this verse line:

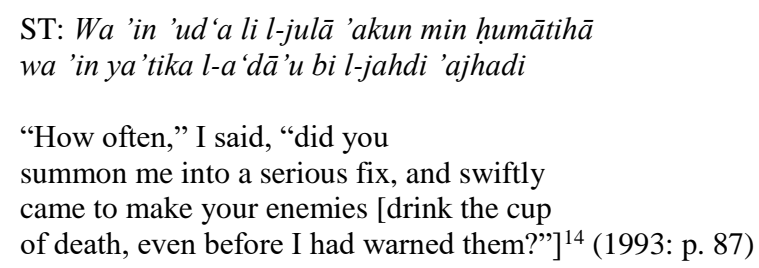

Like O'Grady, Nouryeh effaced the pleonasm, for when he translated verse line 72, and he did not render the message of its second hemistich. As discussed above, Tarafa exposes in this verse line his worth as a brave warrior who would do anything to defend his tribe, which is part of a valuable asset and a valued quality in pre-Islamic Arabia: muruwwah. In contrast, one could easily, mistakenly, understand from Nouryeh's lines that Tarafa was enumerating what he had already done for his tribe to boast of his personal muruwwah. ${ }^{15}$ 


\section{CONCLUSION}

The translation procedures adopted by the translators in the corpus seem to fall into a pair of dichotomous categories. That is, both the avoidance and the addition of lexical and semantic repletion are selections available to and employed by the translators; opting for one rather than the other is governed by translational norms, general translation tendencies, or the translator's (un)awareness of the ST's stylistic features. Although the use of repetition can have a high textemic value, deep-rooted norms concerning pleonastic structures still have the upper hand in the Arabic tradition. Translators generally aim to create an explicit and transparent TT, by canceling repetition - avoiding redundancy and pleonasm, usually in an attempt to implement the TL poetics. However, when Tennyson imitated the Mu'allaqāt in his poem "Locksley Hall," one of the features that he adopted from Arabic prosody was pleonasm (Lahiani, 2020: p. 41).

A literary translation is a "dynamic communicative act" (Boase-Beier, 2010: p. 36). As Scott puts it, "literary translation is a translation into the literary" (original emphasis, 2010: p. 109); to him, the "continuing survival of the ST is to be measured by its continuing dependency on new readers" (2015: p. 184). The processes of intercession and mitigation exercised by some translators can help explain this tendency in translational language towards intervention to restore the balance between avoidance of repetition and the explicative function of the addition of repetition. The comparative analysis of Sells's and Larcher's translations above proves this argument. To Sells, the "new poem should not be too alien to be appreciated, but it must retain enough of the distinctive character of the original to provide a true encounter" (1989: p. 9). Larcher claims that his main objective is to preserve the orality of the ST, which echoes the style of the Bedouin poet (2000: p. 24). Similarly, a translation that seeks to reproduce all the stylistic features of the ST is generally doomed to produce only a deceptive correspondence, as absent selective appropriation in translation, literariness as well as message will not be in evidence. Johnson's and Berque's translations can be called back to mind to exemplify this. It is generally agreed that translated poetry is expected to speak for its original. It is undeniable, though, that this poetry needs to adhere to the aesthetics and poetics of the TL if it aspires to motivate readership in the receiving milieu. As per the findings of the analysis above, a translation that attempts to document the ST aesthetic choices is not expected to achieve a great deal. The pleonasm depicted in the ST does not bear a stable value; it is dynamic, aesthetic and functional. Only those translators who perceived this feature were able to reflect the functional aesthetics inherent in the ST and at the same time reconcile them to the aesthetics of the receiving languages.

Each translation is the outcome of a specific interpretation of the original text, in every case deeply affected by the individual translator's cognitive background, beliefs, interests, views, situations, and knowledge. It is equally important that a translator be aware of the historical environment and biographical context that led to the production of the ST as that they understand and appreciate the functions of the ST's stylistic choices. It is ultimately the task of the translator, regardless of their approach, to attempt to bridge differences. A translator usually works within their own translation aesthetics, which are developed within the traditions of literary and translational aesthetics in the field in which they work, and the ideas of the translator about, or their interpretation of, the ST. 


\section{END NOTES}

${ }^{1}$ Boase-Beier is referred to extensively in this article as her work marks "the first systematic attempt to apply stylistic theory in the field of translation" (Shen and Fang, 2019: p. 326).

${ }^{2}$ For extensive details of the compilation, editions commentaries of the Mu allaqāt, see Lahiani 2008, pp. 1530 .

${ }^{3}$ Wa qarrabtu bi l-qurbā wa jaddika innan̄̄ matā yaku amrun li l-nakīthati ashhadi

${ }^{4}$ The reader infers the pronoun $h \bar{a}$ to mean the poet's tribe, which is the object of the first-hemistich verb. The inference is implied from the context of the verse.

${ }^{5}$ Polyptoton is using the same root in neighboring words, with different grammatical inflections.

${ }^{6}$ Leech's scale is concerned with English consonants.

${ }^{7}$ As already pointed out above, Schmidt, who published his translation much later than the Blunts, employed the same strategy, using a French idiomatic expression to refer to the poet's seeking help.

${ }^{8}$ The Mu'allaqa of Ibn Kulthūm, verse lines 84 to 91, best exemplify this link between preserving a tribe's honor and protecting its women.

${ }^{9}$ In addition to the puns created while conveying the ST polyptoton, both translations convey the ST movement from covertness to explicitness.

${ }^{10}$ The two quoted here works by Sells include his translations of old Arabic literature.

11 Although chronologically the last in the corpus, Larcher's translation is dealt with here due to the close similarities between it and Sells's translation.

${ }^{12}$ When he translated al-Hārith's Mu 'allaqa, O’Grady omitted verse line 62 most probably because it is perisphrastic, and thus, redundant (Lahiani, 2008: p. 258).

${ }^{13}$ Yuan expands upon the link between the strategies of translation adopted by a translator, their objective and the position of the translation in the receiving canon (2018: p. 80).

${ }^{14}$ The bracketed words translate part of verse line 74. They are included here to complete the flow of the idea.

15 The use of the idiom "serious fix" dates back to Arberry.

\section{REFERENCES}

Al-Adwan, A \& Abuarabialedwan, M. (2019). Handling Semantic Repetition when Translating Arabic Short Stories: The Case of Excerpt from The Book of The Dead. 3L: The Southeast Asian Journal of English Language Studies. Vol. 25(2), 49-60.

Al Khafaji, R. (2010). The Ambivalent Status of Lexical Repetition in English-Arabic Translated Texts. In Shiab, S. M., Rose, M. G. House, J. \& Duval, J. (Eds.). Globalization and Aspects of Translation (pp. 165-190). Cambridge: Cambridge Scholars Publishing.

Arberry, A. J. (1957). The Seven Odes. The First Chapter in Arabic Literature. London: George Allen and Unwin Ltd.

Arberry, A. J. (2014). Translation as Re-narration. In House, J. (Ed.). Translation: A Multidisciplinary Approach (pp. 158-177). London: Palgrave Macmillan.

Berque, J. (1979). Les Dix Grandes Odes Arabes de l'Anté-Islam. Paris: Sindbad.

Blunt, A. \& Blunt, W. S. (1903). The Seven Golden Odes of Pagan Arabia, Known also as the Moallakat. Translated from the Original Arabic by Lady Anne Blunt. Done into English Verse by Wilfrid Scawen Blunt. London: Chiswick Press.

Boase-Beier, J. (2017). Poetry Translation. In Millán, C. \& Bartrina, F. (Eds.). The Routledge Handbook of Translation Studies (pp. 475-487). London: Routledge.

Boase-Beier, J. (2010). Who Needs Theory? In Fawcett, A., Guadarrama Garcia, K. L. \& Parker, R. H. (Eds.). Translation: Theory and Practice in Dialogue (pp. 25-38). London: Continuum International Publishing Group.

Boase-Beier, J. (2020). Translation and Style. Oxford: Routledge.

Caussin de Perceval, A. P. (1847). Essai sur l'Histoire des Arabes Avant l'Islamisme, Pendant l'Epoque de Mahomet, et Jusqu'à la Réduction de Toutes les Tribus sous la Loi Musulmane. Paris: Librairie de Firmin Didot Frères.

Debbas, M \& Haider, A. Overcoming Cultural Constraints in Translating English Series: A Case Study of Subtitling Family Guy into Arabic. 3L The Southeast Asian Journal of English Language Studies. Vol. 26(1), 1-17.

Gutt, E-A. (1991). Translation and Relevance: Cognition and Context. Oxford: Basil Blackwell. 
Johnson, F. E. R. A. (1894). Al Sab' Mu 'allaqāt: The Seven Poems Suspended in the Temple at Mecca. Translated from the Arabic by Capt. F. E. Johnson, R. A. With an Introduction by Shaikh Faizullabhai, B. A. London: Luzac \& Co.

Jones, W. (1782). The Moallakät, or Seven Arabian Poems, which were Suspended on the Temple at Mecca; with a Translation, a Preliminary Discourse, and Notes. London: Elmsly.

Koster, C. (2014). Literary Translation. In Juliane House (Ed.). Translation: A Multidisciplinary Approach (pp. 140-157). London: Palgrave Macmillan.

Krein-Kühle, M. (2014). Translation and Equivalence. In House, J. (Ed.). Translation: A Multidisciplinary Approach (pp. 15-135). London: Palgrave Macmillan.

Lahiani, R. (2008). Eastern Luminaries Disclosed to Western Eyes. A Critical Evaluation of the Translations of the Mu'allaqât into French and English (1782-2000). New York, Peter Lang.

Lahiani, R. (2020). Unlocking the Secret of Locksley Hall. Comparative Critical Studies. Vol. 17(1), $25-46$.

Larcher, P. (2000). Les Mu'allaqāt: Les Sept Poèmes Préislamiques. Saint-Clément-de-Rivière: Fata Morgana.

Leech, G. N. (1984). A Linguistic Guide to English Poetry. New York: Longman.

Robert, P. Le Robert. Dictionnaire Alphabétique et Analogique de la Langue Française. Les Mots et les Associations d'Idées. Ouvrage Couronné par l'Académie Française. Paris: Société du Nouveau Littré, 1974.

Monroe, J. T. (1972). Oral Composition in Pre-Islamic Poetry. Journal of Arabic Literature. Vol. 3, 1-52.

Montgomery, J. E. (1986). Dichotomy in Jāhilī Poetry. Journal of Arabic Literature. Vol. 17, 1-20.

Nouryeh, C. (1993). Translation and Critical Study of Ten Pre-Islamic Odes. Traces in the Sand. Lewiston: The Edwin Mellen Press.

O'Grady, D. (1990). The Seven Arab Odes. An English Verse Rendering with Brief Lives of the Seven Poets. Dublin: Agenda Editions.

Schmidt, J-J. (1978). Les Mou 'allaqat, ou un Peu de l'Ame des Arabes Avant l'Islam. Paris: Seghers.

Scott, C. (2010). Re-theorizing the Literary in Literary Translation. In Fawcett, A., Guadarrama Garcia, K. L. \& Parker, R. H. (Eds.). Translation: Theory and Practice in Dialogue (pp. 109-127). London: Continuum.

Scott, C. (2015). Literary Translation and the Rediscovery of Reading. Cambridge: Cambridge University Press.

Sells, M. (1986). The Mu'allaqa of Tarafa. Journal of Arabic Literature, Vol. 17, 21-33.

Sells, M. (1989). Desert Tracings. Six Classic Arabian Odes by 'Alqama, Shanfara, Labìd, 'Antara, al-A'sha, and Dhy al-Rümma. Middletown: Wesleyan University Press.

Shen, D. \& Fang, K. (2019). Stylistics. In Washbourne, K. \& Van Wyke, B. (Eds.). The Routledge Handbook of Literary Translation (pp. 325-337). London: Routledge.

Stetkevych, J. (1993). The Zephyrs of Najd. The Poetics of Nostalgia in the Classical Arabic Nasīb. Chicago: University of Chicago Press.

Sullivan, C. (2019). Poetry. In Washbourne, K. \& Van Wyke, B. (Eds.). The Routledge Handbook of Literary Translation (pp. 268-281). London: Routledge.

El Tayib, A. (1983). Pre-Islamic Poetry. In Beeston, A. F. L., Johnstone, T. M., Serjeant, R. B., Smith, G. R., Menocal, M. R., Scheindlin, R. P. \& Sells, M. (Eds.). Arabic Literature to the End of the Umayyad Period (pp. 27-113). Cambridge: Cambridge University Press.

Underhill, J. (2016). Voice and Versification in Translating Poems. Ottawa: University of Ottawa Press.

Yuan, M. (2018). Translation, Modernity, Acceptability-From Language Reform to Cultural Resistance in Translation Practice in China. 3L The Southeast Asian Journal of English Language Studies. Vol. 24(3), $72-82$. 